DOI: $10.15503 /$ jecs20151.55.64

\title{
SYLVIA PLATH AND THE DANGERS OF BIOGRAPHY
}

\author{
Selma Asotić \\ (9) $\odot \Theta \Theta$ \\ University of Sarajevo, Faculty of Philosophy \\ Bosnia and Herzegovina, 71000 Sarajevo, Franje Račkog 1 \\ E-mail address: asoticselma@gmail.com
}

\begin{abstract}
2013 marked the $50^{\text {th }}$ anniversary of the death of Sylvia Plath and was commemorated by a flurry of new publications on the life and work of the late poet. The renewed interest in Sylvia Plath also revitalized the decades-old debate on the interdependence of her poems and her biography. This paper investigates and problematizes the way in which poetry in general and the work of Sylvia Plath in particular are read and interpreted. It tries to shed some light on the "biographical fallacy" which has for so long plagued critical approaches to her work and shows ways in which S. Plath's own poetic method differs from the method of confessional writers such as Robert Lowell, in the hope of revealing why S. Plath's work cannot and should not be approached through the prism of her biography.
\end{abstract}

Keywords: confessional, poetry, Sylvia Plath, biography

It is easy to imagine the scene: the eery stillness of a snowed-in London, the bleak light of dawn seeping through the curtains, a woman crouched over her writing table, black ink on the pink Smith memorandum paper. The night's darkness is now petering away and the quiet streets prepare for the commotion and bustle of life. An infant's shriek, and the woman stops writing in mid-line, rising from her chair. Her day has now officially begun, and it will be a while before she returns to that stanza she has been musing over for hours. The woman is of course Sylvia Plath, the poet living in the apartment once inhabited by William Butler Yeats, clawing her way through a historically harsh winter and writing some of the best poetry of her life. It is easy to give in to temptation and surrender to the myth of Sylvia Plath. One needs only to listen to the recordings of poems she made for the BBC in 1962: they start at a high-pitched tone of a too self-conscious performer. But then her voice drops deeper and deeper, she nests herself in the sound of her words, forgetting about the audience, forgetting about the interviewer fidgeting in his chair. You become attentive to that voice that has at one particular moment anchored itself in a far off, inaccessible place, you follow it in its slightest undulations, wondering where the tide will take you. By the time the reading finishes, you are thoroughly hooked.

It is easy, but irresponsible to surrender to the myth. Sylvia Plath must have suffered the cruelest destiny to befall any artist: the facts of her life have obscured her literary work. 2013 marked the 50 th anniversary of the poet's gruesome death 
and was commemorated by dozens of new publications, including two new biographies and a re- issuing of her semi-autobiographical novel The Bell Jar. Numerous authors have dissected the life story of Sylvia Plath with morbid curiosity, some going so far as to try and diagnose the mental illness from which she was suffering. Such posthumous brooding over her mental health, an insistence on the pathological defects of her mind which were responsible for her poetry, is unique in literary criticism. No other author has received such misplaced scrutiny.

What is it about Sylvia Plath that makes us deliberate on the facts of her biography, and consequently, display undeserved condescension to her work? Instead of treating her poetry for what it really is - a fictional, artistic product of her mind - readers and critics alike tend to view it merely as a collection of overt signals pointing to controversial, real life events. This paper will focus on two aspects of the problem. One is of a more general nature pertaining to the way readers usually approach poetry. The other is more specific, pertaining to the poetics of a particular literary period that has influenced and shaped our reading of Sylvia Plath. We shall discuss each of them in turn in an attempt to shed some light on the genesis of the mistreatment of the American poet.

One of the reasons behind the "biographical fallacy" is the general predisposition to view poems as expressions of the inner life of the poet. Prior to the literary revolution that was Romanticism, poetry was interpreted in its relation to two elements of the creative process: the referent and the recipient. In lieu of this critical practice, poetic works were considered to be either artistic mirrorings of the outside world (i.e. had a predominantly mimetic function) or moral statements intended to affect the attitudes and worldviews of the readers (i.e. having pragmatism at the heart of its role) (Abrams, 1971, pp. 3-14). It was only when William Wordsworth defined the lyric poem as the "spontaneous overflow of powerful feelings" $(2003$, p. 8$)$ that the critical pendulum decidedly swung to the third, crucial element: the poet as the producer of the work.

The poet's personality now found its way into the center of attention. The lyric became an exclusively subjective form, a product of a hyper-sensitive artist susceptible to the least irritation of the senses. The poet came to be viewed as a medium, refracting external impressions onto the page. Therefore, $\mathrm{W}$. Wordsworth's own poetry was often approached through other, non-literary material, such as his letters or biographical sketches, because to delve into the mind which produced the poem was considered as coming a step closer to unlocking the secret of the aesthetic product itself.

It is not hard to understand this centuries long preoccupation with the figure of the genius poet, this all too human need to uncover true beginnings and anchor such a mysterious process as creative writing to an easily identifiable source. The institution of the author (to borrow the rhetoric of Michel Foucault) enables us to tame the forever volatile, uncontrollable nature of discourse. And this need is nowhere better expressed than in the case of Sylvia Plath, a poet who comfortably traversed the extreme regions of human experience and laid before our eyes all the disturbing facets of life and death. In her poems, Plath travels to the edge of the unspeakable, briefly flirts with the abyss, before finally taking a step back. 
Through excess, she widens the expressive possibilities of language which is why reading Sylvia Plath is always an act of blind faith, an act of choosing to step into a newly chartered space that she has won for us. This stepping out of bounds becomes all the more daunting when the reader is familiar with the sacrifice the poet ended up paying for her fearless transgression.

Those who like to pick through biographies of Plath in order to find out more about the real, flesh-and-blood person behind the poems often forget that even then they are dealing with fictionalized accounts. Legions of readers seem to turn a blind eye to the fact that the posthumous recountings of the poet's life do not offer us the "true" Sylvia Plath, but rather a subjective, carefully constructed persona, a Sylvia Plath that evolved in the mind of the biographer. Regardless of the many rhetorical tricks they may employ to achieve a sense of impartiality, biographers always approach their subject from a limited, highly subjective point of view, and therefore always reveal their particular agenda. Relying on Plath's journals and letters to shed more light on the biographical background to her poetry proves to be an even more precarious task. Plath's letters to her mother are particularly notorious for their cheerful, optimistic tone and for the discrepancy between the nature of real-life events and the manner in which they were conveyed to her family. In March 1956, for example, after experiencing a bout of utter loneliness and desolation in Paris, Plath writes in her journal: "Lazed in bed this morning, weary from the late night and wrote a letter to mother which gave her the gay side" (2000, p. 1544). Plath often used her journals as exercise books in which she worked on and improved her style, wrote down ideas for future novels, lists of possible character names, and it might be much more worthwhile to examine her personal writing as a testing ground for poetic strategies, a free exploration of language. The journals can hardly be a reliable source of information in the case of a scribomaniac like Plath who considered everything an excuse for writing. Plath had a severe knack for mythopoeia and seemed to enjoy mythologizing herself primarily. Let us not forget this fact when we scour through her journal entries to uncover concrete impulses behind her poems: even when writing for herself, Plath never stopped being a writer, she never stopped using language as a coping mechanism, a means to manipulate and transcend reality.

But there is a graver fault still to be found in this incessant treatment of Plath's poems as biographical records. Underlining the effort to extract the life from the poetry is an anachronistic, naive faith that language is benign, a thing supple and translucent, a system of signifiers too ready to yield before an inquisitive eye the bare, denoted signified. It means to deny the poems of Sylvia Plath the nature of aesthetic objects, to deny they are poetry at all. Words in poetry, as Jean-Paul Sartre noted, are not signs but things, "natural things which sprout naturally upon the earth like grass and trees" (1988, p. 29). Under the all-encompassing gaze of the demiurg poet words congeal into sonorous bodies, soaking up the world and mirroring it in its myriad aspects. Nothing escapes the almighty pull of words, their single-minded, autonomous will. Whatever trace of the poet's personal preoccupations and impulses might exist, they are destined to become subsumed within the internal logic of the word-object. Speaking of the difference between prose and poetry, J.P. 
Sartre writes: "In so far as the writer of prose exhibits feelings, he illustrates them; whereas, if the poet injects his feelings into his poem, he ceases to recognize them; the words take hold of them, penetrate them, and metamorphose them; they do not signify them, even in his eyes. Emotion has become thing; it now has the opacity of things; it is compounded by the ambiguous properties of the words in which it has been enclosed. And above all, there is always much more in each phrase, in each verse (...) The word, the phrase-thing, inexhaustible as things, everywhere overflow the feeling which has produced them" (1988, p. 34). Denying this peculiar nature of language in poetry seems especially wrong in the case of Sylvia Plath, a disciplined wordsmith who displayed an acute sense for the materiality of the word, its dizzying connotative depths, its magical swaying rhythms.

Now we come to the other reason behind the biographical (mis)reading of Sylvia Plath: the labeling of her work as "confessional". Confessional poetry was a mode of writing born in mid-twentieth century America which brought about a decisive break with Modernist formalism and insistence on impersonality. The term was first used by Macha Louis Rosenthal who applied it disparagingly in a review of Robert Lowell's Life Studies, the poetry collection which marked the beginning of the confessional trend in literature. M.L. Rosenthal wrote: "Lowell removes the mask. His speaker is unequivocally himself, and it is hard not to think of Life Studies as a series of personal confidences, rather shameful, that one is honor-bound not to reveal" (Dowson, 2011, p. 65). This sense of impropriety was undoubtedly caused by the confessional breakthrough into thematic fields and manners of address unbeknownst to earlier poetic works, especially those of the High Modernists who preceded Plath's generation and whose sense of poetic decorum and insistence on the technical achievements of the poem the confessionals rebelled against. David Dalton Yezzi provides us with a useful working description of the confessional style:

"What makes a poem confessional is not only its subject matter - e.g., family, sex, alcoholism, madness - or the emphasis on self, but also the directness with which such things are handled. Unflinching and generally extreme in their diction and address (certainly compared to what preceded them), the poems of Snodgrass, Lowell, Sexton, and Plath comprise a wide tonal range from sad whisper to hectoring squawk. What they have in common, what sets them apart from other poems that incorporate details from life, is their sense of worn-on-the-sleeve self-revelation and their artful simulation of sincerity. By relying on facts, on »real« situations and relationships, for a poem's emotional authenticity, the poet makes an artifice of honesty. Confessional poems, in other words, lie like truth" (Yezzi, 1998).

D.Yezzis's statement of the "artifice of honesty" is very important in understanding the nature of the confession in poetry. Faced with an arbitrary system of signs, an endless chain of signifiers referring back to one another, a web of silences that is language, the poet can only offer up an illusion of truthfulness. Therefore, biography once again fails to provide a reliable means of interpretation. Once the 
poet steps into the symbolic order, he/she must negotiate between experience and language. There is no absolute truth hiding outside words - words are their own truth.

The scandal of the confessional mode of writing and its use of subject matter previously thought unfit for inclusion in poetry can only be understood in relation to the era in which it originated. Cold War America was a place of shifting notions and values. One of the most important debates at the time centered around the issue of privacy. As Deborah Nelson notes in Pursuing Privacy in Cold War America, the right to privacy was long considered to be one of the most important features of democratic societies, opposing the intrusiveness of totalitarian regimes. However, Cold War surveillance and other developments in all spheres of life brought into question the neat division between the private and the public sphere. Old notions of privacy being tied to the topos of the family home underwent serious revision as the home ceased to be a unique respite from public affairs and instead became a new political battleground. Not only did the state now actively penetrate the home, but the mixing of the private and public spheres also developed in the opposite direction, through the shift in the use of confession. Lowell enraged Rosenthal and many other readers and critics by daring to topple the sanctity of the patriarchal home, firmly established on taciturn notions of decorum and propriety. Take, for example, this poem by Lowell, Father's Bedroom:

"In my Father's bedroom:

blue threads as thin

as pen-writing on the bedspread,

blue dots on the curtains,

a blue kimono,

Chinese sandals with blue plush straps.

The broad-planked floor

had a sandpapered neatness.

The clear glass bed-lamp

with a white doily shade

was still raised a few

inches by resting on volume two

of Lafcadio Hearn's

Glimpses of unfamiliar Japan.

Its warped olive cover

was punished like a rhinoceros hide.

In the flyleaf:

»Robbie from Mother $«$.

Years later in the same hand:

»This book has had hard usage

On the Yangtze River, China.

It was left under an open

porthole in a storm «" (1980, p. 75). 
The very title of the poem indicates Lowell's gigantic leap into forbidden domains. The poetic persona (who is identical to the author) is stepping into the consecrated place of any household - the parental bedroom. But the offense is aggravated by the fact that it is the patriarch of the household who is being subjected to the prying investigation. Instead of a domineering, controlling figure, Lowell's father is the dominated one, vulnerable to the intrusions of others, devoid of a private space, whereas in the traditional patriarchal code the Father was the one who ensured the integrity of the home: the privacy of the family circled around the patriarch as the bearer of the family name and the keeper of its sanctity. Throughout Life Studies, the father figure is diminished and ridiculed, turned into a mockery of the earlier patriarchal sovereign. Lowell invests his father with an air of forbidden femininity: in Father's Bedroom, the poet's eye is fixed on the delicacy and neatness of the objects. His descriptions convey an air of the fragile quality of things left behind. Together with the poet, we are surveying the deserted chambers of a failed monarch; traces of royal blue speak of his conspicuous absence, the estrangement between father and son underscored by the exoticism of faraway lands, of "Chinese sandals with blue plush straps". The acidic rains of time have slowly nibbled away at Lowell's aristocratic family lineage, just as the storm punished the olive covers of the book.

Comparing Lowell's poem to Sylvia Plath's Daddy might be a good starting point from which to elaborate Sylvia Plath's approach to poetry and the way she intersects with and differs from her contemporaries. In her essay Sylvia Plath and Confessional Poetry: A Reconsideration, critic Margaret Dickie Uroff draws attention to the different usage of poetic persona in Lowell and Plath. She writes:

"Lowell himself has said that while he invented some of his autobiography, he nonetheless wants the reader to feel it is true, that he is getting the real Robert Lowell. The literal self in Lowell's poetry is to be sure a literary self, but fairly consistently developed as a self-deprecating, modest, comic figure with identifiable parents, summer homes, experiences at particular addresses. When he discloses under these circumstances his weaknesses, his ineptitude, his misery, his inflicting of pain on others, he is in fact revealing information that is humiliating or prejudicial to himself. In this sense, the person in the poem is making an act of confession, and, although we as readers have no power to forgive, Lowell's self-accusatory manner makes it impossible to judge. We are not outraged but chastened by such revelations. With Plath, it is otherwise. The person in her poem calls certain people father or mother but her characters lack the particularity of Commander and Mrs. Lowell. They are generalized figures not real-life people, types that Plath manipulates dramatically in order to reveal their limitations. Precisely because they are such types, the information that Plath reveals about them is necessarily prejudicial and has consequently misled some readers who react with hostility to what she has to reveal" (Uroff, 1977).

Lowell does not conceal the personal I. His poetry gains universal meaning because the poet and the world mirror each other: the story of the slow decline of Lowell's family is a metaphor for the downfall of an entire social order. When 
Lowell speaks of his suffering, his mental breakdown, his inability to be a good father, he is at the same time diagnosing the state of the world. Although the term confessional has come to denote narcissism and a move away from society, Lowell's poems are social in their nature. In them, Lowell inscribes not simply his personal anguish and fears, but the fears of an entire generation caught in the bedlam of Cold War politics.

Sylvia Plath's poetry is equally political. It brings into the public sphere those aspects of the feminine domestic experience which have been systematically ignored and excluded from public discourse. Plath voices the anxieties of the self trapped within a hostile world, she transforms the terms of her confinement by bringing them into the creative process where she can manipulate and transcend them. Plath may start off from concrete experience but unlike Lowell she seeks to hide the personal I, or at least move away from it as much as possible. Plath's formal ingenuity, her lucid rhythms and frequent use of irony serve as methods of detachment. The Daddy Plath speaks of stops being the biographical Otto Plath and becomes an element in Plath's unique mythological system. It therefore seems particularly unfair to reduce to biographical trivia a body of work of a poet who desperately sought to transcend biography, to work out a way of verbalizing the most traumatic, silence-stricken experiences.

Daddy, "the "Guernica " of modern poetry" in which Plath managed "the classical act of generalization, translating a private, obviously intolerable hurt into a code of plain statement" (Steiner, 1965), contains the oft repeated narrative of liberation, a mythological pattern that seems to structure most of Plath's poetry. The gruesome showdown with the father figure starts off with a grotesque rhythm of a nursery rhyme:

"You do not do, you do not do

Any more, black shoe

In which I have lived like a foot

For thirty years, poor and white,

Barely daring to breathe or Achoo.

Daddy, I have had to kill you.

You died before I had time--

Marble-heavy, a bag full of God,

Ghastly statue with one gray toe

Big as a Frisco seal.

... I never could tell where you

Put your foot, your root,

I never could talk to you.

The tongue stuck in my jaw.

It stuck in a barb wire snare.

Ich, ich, ich, ich,

I could hardly speak" (1981, p. 222). 
In Daddy, decoding the nightmares of personal history leads to an attempt to exorcise the demons haunting the collective social body. Therefore, breaking free cannot be done by revisiting one's private past, as is the case in Lowell, but by shedding away the burden of an unwanted, uncalled for historical heritage. In both Father's Bedroom and Daddy, the speakers find themselves in foreign territory, feeling alien in spaces which were supposed to be their home. But while Lowell's space is the family house where he is trying to reconstruct the story of his father and his own childhood, Plath megalomaniacally traverses the ghastly landscape of post-WWII Europe in an attempt to locate and overcome the shackles that bind her. Her outrageous hyperboles testify to her desire of endowing her poems with an almost cosmic relevance. Lines such as: "The grasses unload their griefs on my feet as if I were God/ Prickling my ankles and murmuring of their humility" (Plath, 1981, p. 172) are not mere evidence of Plath's ego mania. They are expressions of her instinctual desire to detach herself as much as possible from private concerns and achieve a universal appeal. Whether she succeeds in it or not is a matter of poetics not biography.

Speaking of her approach to poetry in a 1962 interview, Plath states: "I think my poems immediately come out of the sensuous and emotional experiences I have, but I must say I cannot sympathise with these cries from the heart that are informed by nothing except a needle or a knife, or whatever it is. I believe that one should be able to control and manipulate experiences, even the most terrific, like madness, being tortured, this sort of experience, and one should be able to manipulate these experiences with an informed and an intelligent mind. I think that personal experience is very important, but certainly it shouldn't be a kind of shut-box and mirror looking, narcissistic experience. I believe it should be relevant, and relevant to the larger things, the bigger things such as Hiroshima and Dachau and so on" (Orr, n.d.). Plath obviously felt that her interest in portraying aberrant states of mind and extreme experiences might lead to nothing more than hysterical "cries from the heart". Therefore she took great pains to create poetic personas, fictionalized speakers whose adversities she could then explore from a safe distance and reveal the universal aspects of their situation.

In Daddy, the roots of the speaker's pain do not lie in an isolated, private experience but are brought into connection with a civilizatory affront. While through confession Lowell hopes to descend into the most distant depths of his identity, to fill in the gaps in his memories in order to re-affirm himself, Sylvia Plath does not want to confess her being, and thereby validate it. On the contrary: she wants to break free from herself, she seeks an escape. In her essay A Fine, White Flying Myth: The Life/Work of Sylvia Plath, Sandra Gilbert describes Plath's "mythological method" in the following manner: "Being enclosed - in plaster, in a bell jar, a cellar, or a wax house - and then being liberated from an enclosure by a maddened or suicidal or "hairy and ugly avatar « of the self is, I would contend, at the heart of the myth that we piece together from Plath's poetry, fiction, and life (...) The story told is invariably a story of being trapped, by society or by the self as an agent of society, and then somehow escaping or trying to escape" (1979, p. 251). What Plath offers through her numerous personas is a host of planned, highly 
controlled performances in which she manages to reinvent herself and constantly widen the scope of her experience.

There is one more aspect of Sylvia Plath's poetry and confessional writing we need to consider. Foucault describes confession as "a ritual of discourse in which the speaking subject is also the subject of the statement; it is also a ritual that unfolds within a power relation, for one does not confess without the presence (or virtual presence) of a partner who is not simply the interlocutor, but the authority who requires the confession, prescribes and appreciates it, and intervenes in order to judge, punish, forgive, console and reconcile (...) The agency of domination does not reside in the one who speaks (for it is he who is constrained), but in the one who listens and says nothing; not in the one who knows and answers, but in the one who questions and is not supposed to know" (1978, p. 61-62). If confession is to have a therapeutic effect, if it is to allow an objective distancing from the self in order to uncover the truth of one's experience, then the virtual presence of a future reader/listener is its indispensable part. In Lowell's case, the readers are his silent accomplices. The simple lexicon and syntax of Life Studies points to Lowell's desire to come across, to be understood. We embark on the journey into the darkest pits of the poet's psyche with an empowering feeling that our presence alone is able to render true the agonizing outpourings of the poet's heart. Poetry is no longer, as John Stuart Mill claimed, overheard. Instead, the poet asks for our participation, he invites us to bid our ears to his woe.

On the other hand, one of the most disturbing aspects of reading Sylvia Plath's poetry is her perfect contempt for the audience. Lady Lazarus might perform her "big strip tease" before a bustling "peanut-crunching crowd", but in the Ariel collection as a whole, the reader is not needed. Plath is not seeking our sympathy, validation or consolation. She is single-mindedly moving to a destination not reachable to us, she is "the arrow,/The dew that flies/Suicidal, at one with the drive/Into the red/Eye, the cauldron of morning" (1981, p. 239). In her great journey of liberation, of breaking free from an imposed, stilted self, Plath disturbs us by not needing us. At her worst, she recedes into a sort of isolated autarchy, becoming stuck in a vivid but also hermetic mental landscape. Once again, the reader does not overhear the poetry: he/she becomes trapped in the poet's mind, a hostile place filled with undecipherable yelps and shrieks. At her best, Plath achieves a controlled autonomous expression, with universal significance.

In conclusion: using biographical investigation as a reliable interpretative method should be avoided both as a general reading practice and as a way of approaching the poetry of Sylvia Plath. The peculiar nature of words in poetry makes biographical reading a rather futile endeavor. Although personal experiences are very often the impetus behind a poetic work, this raw material never escapes the totalitarian will of the creative process which distills from it the meaning and the purpose required by the poem. It is this self-willed nature of poetry that allowed Sylvia Plath to express that which was stubbornly steeped in silence. It allowed her not to confess herself like the majority of her contemporaries, but to 
multiply and disfigure herself, thus galloping away into psychic territories that would have otherwise remained outside of her reach. Her poetry is conceived in a moment of impenetrable isolation and silence before exploding into the world in a fury of language that will spare no reader and revere no confessor.

Plath's premature death means we will never know in which direction she would have evolved as a poet had she lived on. The popularity of poems such as Daddy and Lady Lazarus has obscured the more satisfying achievements, such as Berck-Plage and Edge in which, as Helen Vendler notes, Plath achieves an impeccable, impersonal style (2010, p. 55). But we do own Sylvia Plath a closer examination of her poetic oeuvre without the intrusions of the spectacular biographical facts. A poet who did not mind sacrificing her life for the "blood-jet of poetry" surely deserves to be treated as a poet (a good or a bad one, it is up to the individual taste, but a poet nonetheless) and not as a study case for pathological states of mind.

\section{REFERENCES}

Abrams, M.H. (1971). The Mirror and the Lamp: Romantic Theory and the Critical Tradition. New York: Oxford University Press.

Foucault, M. (1978). The History of Sexuality. New York: Pantheon Books.

Gilbert, S. (1979). A Fine, White Flying Myth: The Life/Work of Sylvia Plath in Shakespeare's Sisters: Feminist Essays on Women Poets. In: S. Gilbert, \& S. Gubar (Ed.). Shakespeare's Sisters: Feminist Essays on Woman Poets. Bloomington: Indiana University Press.

Gill, J. (Ed.) (2006). Modern Confessional Writing: New Critical Essays. London: Routledge.

Lowell, R. (1980). Life Studies and For The Union Dead. New York: The Noonday Press.

Mill, J.S. (n.d.). Thoughts on Poetry and Its Varieties. Retrieved February 28, 2014 from http:/ / www.laits. utexas.edu/poltheory/jsmill/diss-disc/poetry/poetry.s01.html.

Nelson, D. (2002). Pursuing Privacy in Cold War America. New York: Columbia University Press.

Orr, Peter (n.d.) A 1962 Sylvia Plath Interview with Peter Orr. Retrieved October 13, 2014 from http:// www.english.illinois.edu/maps/poets/m_r/plath/orrinterview.htm.

Plath, S. (1981). The Collected Poems. In: T. Hughes (Ed.). New York: Harper and Row.

Plath, S. (2000). The Unabridged Journals of Sylvia Plath. In: K.V. Kukil (Ed.). New York: Anchor Books.

Sartre, J.P. (1988). What is Literature and Other Essays. Cambridge, MA: Harvard University Press.

Steiner,F.G. (1965). Dying is an Art. Retrieved from http:/ / www.unz.org/PubReporter-1965oct07-00051.

Uroff, M.D. (1977). Sylvia Plath and Confessional Poetry: A Reconsideration. Retrieved from http://www. sylviaplath.de/plath/ uroff.html.

Vendler, H. (2010). Last Looks, Last Books: Stevens, Plath, Lowell, Bishop, Merrill. Oxford: Princeton University Press

Wordsworth, W., \& Coleridge, S.T. (2003). Lyrical Ballads and Other Poems. Ware, UK: Wordsworth Editions Ltd.

Yezzi D. (1998). Confessional Poetry and The Artifice of Honesty. Retrieved from https://www.newcriterion.com/articles.cfm/Confessional-poetry---the-artifice-of-honesty-3026 